Article

\title{
Strategy for Sustainability of Social Enterprise in Indonesia: A Structural Equation Modeling Approach
}

\author{
Putri Mega Desiana ${ }^{1,2}, * \mathbb{C}$, Mohamad Syamsul Ma'arif ${ }^{1}$, Herien Puspitawati ${ }^{3}$, Riani Rachmawati ${ }^{2}$, \\ Ruslan Prijadi ${ }^{2}$ and Mukhamad Najib ${ }^{4}(\mathbb{D}$ \\ 1 School of Business, IPB University, Bogor 16151, Indonesia; syamsul4958@gmail.com \\ 2 Department of Management, Universitas Indonesia, Depok 16424, Indonesia; \\ riani.rachmawati@ui.ac.id (R.R.); ruslan.prijadi@ui.ac.id (R.P.) \\ 3 Department of Family and Consumer Sciences, IPB University, Bogor 16680, Indonesia; \\ herien_puspitawati@email.com \\ 4 Department of Management, IPB University, Bogor 16680, Indonesia; najib@apps.ipb.ac.id \\ * Correspondence: putri.mega71@ui.ac.id
}

check for

updates

Citation: Desiana, P.M.; Ma'arif, M.S.;

Puspitawati, H.; Rachmawati, R.;

Prijadi, R.; Najib, M. Strategy for Sustainability of Social Enterprise in Indonesia: A Structural Equation Modeling Approach. Sustainability 2022, 14, 1383. https://doi.org/ $10.3390 /$ su14031383

Academic Editors: João Carlos Correia Leitão and Dina

Batista Pereira

Received: 5 December 2021

Accepted: 21 January 2022

Published: 26 January 2022

Publisher's Note: MDPI stays neutral with regard to jurisdictional claims in published maps and institutional affiliations.

Copyright: () 2022 by the authors Licensee MDPI, Basel, Switzerland. This article is an open access article distributed under the terms and conditions of the Creative Commons Attribution (CC BY) license (https:// creativecommons.org/licenses/by/ $4.0 /)$.

\begin{abstract}
Social enterprise (SE) is a significant global phenomenon that occurs when an organization with social concerns can grow concurrently with its commercial activities. However, the factors that influence the sustainability of SE remain relatively understudied. This study argues that innovation is a prerequisite for SE's sustainability. Therefore, this study aims to find alternatives to SE's sustainability strategy, considering the need for SE to have dynamic capabilities, to anticipate changes in the ecosystem, and to manage the company's internal resources to build on SE's innovation and sustainability. The dataset was obtained from a survey of 187 SEs in Indonesia, which was then processed using SEM. Results indicate that internal factors have no direct significant effect on sustainability, but the ecosystem and innovation have been shown to have a direct and significant positive effect on sustainability. Dynamic capabilities have a significant but negative direct relationship to sustainability. Internal and ecosystem factors cannot be mediated by dynamic capabilities when it comes to sustainability, whereas innovation can only mediate internal factors towards sustainability. Finally, serial mediation of dynamic capabilities and innovation are key elements that contribute to sustainability. It is proven that if dynamic capabilities are directed to foster innovation, it will increase sustainability.
\end{abstract}

Keywords: sustainability; strategy; dynamic capability; innovation; social enterprise; social entrepreneurship

\section{Introduction}

Social Enterprise (SE) is a worldwide phenomenon that has had a major impact on communities and society [1-3]. SE has just developed as a research field and is extensively used to address social problems all around the world [4]. SE is capable of resolving economic disparities as well as social or environmental issues, and it is regarded as successful in empowering marginalized communities by providing access to education, low-cost health care, and assisting those who have been neglected to become useful members of society $[3,5]$.

In contrast to commercial businesses, which are driven solely by profit, SE is driven by a social mission in that the majority of earnings are reinvested in the beneficiaries or the community. However, SE still has to ensure the availability of funds so that the business continues to operate [6]. Complexity, even the conflict between efforts to achieve social missions (benefits for the community) and the need to maintain the availability of funds, often causes SE to experience difficulties, even not be able to survive [7]. The success of combining these two things is a prerequisite for SE's sustainability $[6,8]$. 
The notion of SE is important to develop in Indonesia since many societal problems that have not been adequately handled result in unmet demands (market failure). Many people remain impoverished, and trash that has not been adequately handled may eventually cause health concerns, a lack of clean water, and other issues that preclude possibilities for SE to expand and flourish in Indonesia [9].

Although most of the social services are still relatively small and their scope is still limited, they have a positive impact on the welfare of the people involved in them; therefore, the sustainability of social services is very important. André and Pache explained that SE is an entrepreneurial activity used to fulfil a social mission, such as developing a community, increasing welfare, or creating a healthier environment [10]. SE's main purpose is social, while commercial efforts are carried out as a support to achieve the main goal [11,12].

With this understanding, SE sustainability requires that SEs must be able to maintain their social goals and at the same time must be able to obtain financial support from time to time [6,7]. Business sustainability requires innovation [13-15]. Innovation itself is inseparable from various factors, including company resources, access to resources, entrepreneurial orientation, leadership, and personal characteristics [16,17]. At the internal SE level, business mission, leadership, personal characteristics, and company resources are believed to have an impact on innovation $[18,19]$. Social innovation occurs within the ecosystem, and therefore, will be influenced by the elements of the ecosystem, such as access to finance, access to network, social culture, institutional infrastructure, and government policy $[20,21]$. Moreover, the ability to manage the internal factors to cope with the everchanging environment which would influence the ecosystem is called dynamic capability. Teece, Pisano, and Shuen argued that dynamic capability is an organizational capability to manage resources dynamically, namely integrating, building, and reconfiguring competencies [22]. This capability is a central response in anticipating an everchanging environment. While internal and external factors that influence the sustainability of SE have been explored in previous studies, limited studies have been conducted to understand the role of dynamic capabilities and innovation in enhancing the sustainability of SE. Considering the present state of the gaps in the earlier research, the research questions addressed in this study are: (1) how does the management of the SE's internal factors and ecosystems affect SE sustainability, and (2) what is the intermediary role of dynamic capabilities-based innovation in fostering sustainability.

Furthermore, the general objective of this study is to examine the factors affecting the sustainability of SE. Specifically, this study aims: (1) to discover how internal factors and ecosystems are managed to achieve the sustainability of the SE, and (2) to clarify the role of innovation built through dynamic capabilities as a mediator in creating SE sustainability. This study enriches the social enterprises literature by investigating the mediating function of dynamic capabilities and innovation in determining what management can do to increase SE sustainability.

\section{Literature Review}

SE's sustainability refers to the capacity of SE to continue to fund its organization's activities and have a good social effect today and in the future [23,24]. The long-term existence of an organization depends on the organization's ability to generate its own income as a major contributor to income $[25,26]$.

\subsection{Internal Factors and Sustainability}

The organization's sustainability can be determined by internal factors. These elements typically include the company's vision, mission, resources, and leaders [27-30]. Bart found that the organization's mission will affect innovation and organizational performance [31]. The organization's mission is the most basic manifestation of its identity and ultimate goal: who will be served and how? [32,33]. Marshall, Coleman, and Reason revealed that leadership can be a factor supporting the sustainability of an organization [34]. Entrepreneurial leadership, developed by Renko, El Tarabishy, Carsrud, and Brännback, is one of the best 
leadership theories for social entrepreneurs. Entrepreneurial leadership is defined as leadership that influences and directs group members' performance toward the achievement of organizational goals, which includes recognizing and capitalizing on entrepreneurial opportunities [35]. In addition, personal characteristics also greatly determine whether an organization will continue to grow or stop operating [36].

Growth-oriented small business entrepreneurs are more likely to take risks than managers in large companies [37]. Zimmer stated certain personal characteristics lead to entrepreneurial success [38]. Taking risks is a common factor associated with entrepreneurship. Risk-taking propensity is an individual's proclivity to assume a certain level of risk associated with one's business ventures, particularly when making business decisions [39]. Furthermore, Chipeta and Surujlal stated that other factors, such as proactive personality, are closely related to entrepreneurship [40]. Proactive behavior is defined as creating new opportunities for oneself or taking the initiative to improve current circumstances, and determining how individuals take-action to influence their environment [40,41]. While in terms of organization resources, human capital, such as skills, behaviors, and values, are believed to be an important factor in creating competitiveness and sustainability [29], and lack of financial resources and funding is a major obstacle to sustainability [27]. Based on the explanation given from the results of previous research, the following hypothesis is suggested.

\section{Hypothesis 1 (H1). SE internal factors have a positive effect on sustainability.}

\subsection{Ecosystem and Sustainability}

The entrepreneurial ecosystem is a collection of interconnected elements that influence the formation of productive entrepreneurs and, as a result, add value to the economy, society, and environment [42-47]. Productivity rises as the number of new businesses (start-ups) grow, absorbing a larger number of more productive workers. Similarly, Han and Shah proposed that elements of the ecosystem such as financing, organizations, technology and data, strategies, institutional infrastructure, and government policy would ease the scaling up of the enterprises [21], while Venkataraman found the entrepreneurial ecosystem, or the environment that encourages the formation of new businesses, is a web of interconnected elements that includes risk-takers, information brokers, resource providers, demand markets, and enabling technologies that work together to create a virtuous cycle of wealth creation [46]. Beyond the entrepreneur, some ecosystem components include supporting infrastructure, culture, business support services, policies, and various regulations. Because enterprises are also part of the ecosystem, it is obvious that the performance of the company will affect the quality of the ecosystem.

In addition to internal resources, external components (in this case the ecosystem) are also believed to be able to influence the success and sustainability of a business [48] An entrepreneurial ecosystem is defined as a set of interdependent actors and factors that are coordinated in such a way as to enable productive entrepreneurship within a given area [45]. If it is associated with SE, to support its productivity, the SE ecosystem can be in the form of access to finance, access to networks and social culture that supports $\mathrm{SE}$ to develop. Funding is a factor that can determine the continuation of SE in terms of access to finance [30]. SE funding can vary; historically, SEs have relied on government grants and donor funding [49]. However, SE's financial resources do not come solely from these two sources; SE must also be able to manage the income generated by its business activities. Government funding, donor funding of international organizations, and individual donations are all examples of external funding. Sigasa found that only $45 \%$ of social enterprises generate sufficient revenue from operations to sustain the organization. The remaining 55\% depend on donor funding and other means of survival, such as using personal income and relying on volunteers [30].

Furthermore, the presence of a network increases organizational sustainability [12], because social capital can help organizations obtain resources and information [50]. Ac- 
cess to networks/social capital has proven to be effective in influencing organizations to achieve business sustainability [51]. Community involvement is also important in terms of developing, proposing, and enforcing potential solutions to social problems. High levels of social capital and trust among ecosystem actors have a positive impact on SEs' ability to introduce social innovations [20]. Social culture, the next component of the ecosystem, is the norms of people's behavior, including ethical and moral codes, which are people's reactions to market failures [52]. The community and culture of a location can have a significant impact on the entrepreneurial process [42,53], thus a culture that supports social entrepreneurship is required to encourage the growth and development of social enterprises in a region $[45,54]$. In addition to access to finance and networks, the role of social culture can also affect economic performance [52]. The following hypothesis is proposed based on previous research and the explanation above.

Hypothesis 2 (H2). SE ecosystem has a positive effect on sustainability.

\subsection{Dynamic Capabilities and Sustainability}

Organizations with strong competitive advantages rooted in the company's processes, culture, or mindset are not always able to keep pace with changes in external environmental conditions (e.g., technological changes), and this condition can cause organizations to be late in dealing with these changes. Organizations must constantly update their internal capabilities to deal with these dynamic environmental changes, which are referred to as dynamic capabilities [22].

The ability of a company to integrate, build, and reconfigure internal competencies in the face of a rapidly changing environment is defined as dynamic capabilities [22]. Teece divides dynamic capabilities into three categories: sensing, seizing, and transforming [55]. Dynamic capabilities refer to a company's ability to develop new manufacturing processes and products/services to respond quickly to environmental changes [56]. Meanwhile, other researchers said dynamic capabilities refer to a company's ability to integrate, build, and reuse internal and external resources to be the best and configure to create and develop new capabilities and market opportunities $[57,58]$. Dynamic capabilities are typically embedded in organizational processes and routines that enable businesses to adapt to changing market conditions. sequentially reconfigure their source base, and ultimately gain a competitive advantage [59]. According to research on dynamic capabilities, the ability to reconfigure internal and external capabilities occurs not only in companies facing fast and dynamic environmental changes, but also in companies facing relatively stable environmental conditions [60]. In this case, the learning mechanism will encourage a dynamic capability process.

Finally, establishing a long-term competitive advantage is dependent on the organization of the company's resources and capabilities [57]. In line with this, Eikelenboom and de Jong argued that dynamic capabilities are important in the context of MSMEs because they can help MSMEs overcome resource constraints and increase their level of success in efforts to achieve sustainability [61]. Ince and Hahn found that SE's dynamic capabilities can support business sustainability as long as they are able to seize opportunities and take advantage of them well [62]. Based on the previous research and the explanation above, the following hypothesis is proposed.

\section{Hypothesis 3 (H3). Dynamic capabilities have a positive effect on sustainability.}

\subsection{Innovation and Sustainability}

In its most basic form, innovation is doing something new, useful, and rewarding that requires management to capitalize on [63]. Social innovation is defined as new solutions (products, services, models, markets, processes, organizations, or others) that simultaneously meet social needs (more effectively than existing solutions) and lead to new or improved opportunities and relationships, as well as better use of assets and resources [64]. 
Several researchers contended that innovation is central to the SE process [20]. Furthermore, the use of market-based revenue generation methods is part of the innovation process and, as a result, SE is essentially an innovation process [3]. Entrepreneurship and innovation are inextricably linked because both involve the process of discovering, evaluating, and exploiting opportunities (entrepreneurship) and new things (innovation) [65]. The company's proclivity to experiment, new ideas, and creative processes that can result in new products/services is reflected in innovation [66]. Innovation can take many forms, including incremental improvements and radical breakthroughs. It is possible to conclude that all innovations imply change, but not all changes imply the introduction of new ideas or the achievement of significant improvements [37].

Innovation can be classified into four categories [67-69]. First, product and/or service innovation, which entails changing the organization's products or services by utilizing new or existing technologies. It refers to the creation and promotion of new products and services related to customer satisfaction. The second type of innovation is process innovation, which involves changing the way new products or services are improved. It entails the development of new methods of manufacturing and providing services. Third is marketing innovation, which refers to altering the context in which goods or services are introduced to the market by focusing on consumer needs. Fourth, organizational innovation (management or mental processes) entails changing the underlying mental model. Fontana and Musa stated that one of the dimensions of innovation is continuous innovation in terms of the social impact that comes with it. The positive impact of an organization's innovation created or generated for stakeholders is referred to as sustainable innovation [70]. The dimensions of innovation in this study are divided into five categories based on the characteristics of the society to be studied, namely product innovation, process innovation, marketing innovation, continuous innovation, and open innovation.

The goal of social innovation is to provide outcomes that are relevant to the needs of the community, and this is a problem that the community must face and handle. Employee innovation is required for business sustainability [71], but social innovation is the key for companies to achieve corporate sustainability [13-15]. Therefore, social innovation capacity plays a very important role in achieving organizational sustainability. SE will be sustainable if it has a greater capacity for innovation. The following hypothesis is suggested based on prior research and the explanation above.

Hypothesis 4 (H4). Innovation has a positive effect on sustainability.

\subsection{Mediation of Dynamic Capabilities on Sustainability}

Businesses today operate in a world that is not only riskier but also more volatile, uncertain, complex, and ambiguous [72]. Organizations that are too close to traditional ways of operating will be hindered from achieving success. On the other hand, those who focus on developing new products and processes coupled with business model innovation must enhance their dynamic capabilities. One of the important factors to be able to have a strong dynamic ability is to increase the entrepreneurial leadership of the top management team [73].

The relationship between company resources and dynamic capabilities is often seen as a necessity. McKelvie and Davidsson examined how the relationship between the characteristics of the founders, which are personal characteristics, with dynamic capabilities in the company's efforts to build competitiveness. Conclusively, they found that different founder characteristics define different capabilities [74].

In previous research, $\mathrm{Wu}$ discovered that in achieving performance, the relationship between company resources and dynamic capabilities is very close, where dynamic capability is an intermediary between company resources and performance [58]. Arend discovered the same thing: personal characteristics in SMEs have a positive impact on dynamic capabilities in achieving company performance [75]. 
Dynamic capabilities, in addition to having a relationship with the company's internal factors, are also closely related to its external factors. The original concept of dynamic capability emphasized at least three elements, namely sensing, seizing, and transforming [50], and this concept is still evolving $[56,62,76]$. Sensing and seizing capabilities, according to this concept, are the company's response to the business environment, particularly changes in the market or technology. However, it has been discovered that the business environment is an important factor in developing dynamic capabilities. Eriksson discovered in an extensive literature review that the role of the external environment in building the company's internal capabilities is becoming increasingly important, both in the form of business networks or resources or capabilities from outside the company that can be used to supplement the company's internal capabilities [77]. Small businesses' dynamic capabilities can be gradually developed by utilizing resources from outside their business network [78]. Furthermore, Eikelenboom and de Jong discovered that dynamic capabilities have an impact on business sustainability [61]. Based on the previous research and the arguments presented above, the following hypotheses are proposed.

Hypothesis 5 (H5). Dynamic capabilities mediate the influence of internal factors on sustainability.

Hypothesis 6 (H6). Dynamic capabilities mediate the effect of ecosystems on sustainability.

\subsection{Mediation of Innovation on Sustainability}

Leadership always involves vision [79] and leaders will serve as role models by their subordinates [80]. This means that leaders' ethical behavior must be taken-into account because it plays an important role in promoting innovative ideas in organizations [81]. In the context of entrepreneurial leadership, leaders have an important role in the formation of corporate entrepreneurship. Leadership has an effect on organizational growth capability, one of which is measured by the innovation process [82]. Furthermore, several other researchers studied the relationship between leadership and organizational innovation and concluded that leadership is one of the components supporting the formation of innovation [16,83-85].

Proactive personal characteristics will trigger innovation [19], and this personality will also encourage someone to develop SE [86]. Meanwhile, it is critical to emphasize that financial and human resources are the driving forces behind innovation [17,87].

Entrepreneurial activity, as an output of the entrepreneurial ecosystem, is considered the process by which individuals create opportunities for innovation [45]. Igwe et al. also found that various elements of an ecosystem, such as regulatory norms (formal or informal), access to markets, access to other resources, and culture, as well as the use of technology, will encourage the mechanism of innovation [88]. Entrepreneurs will use this mechanism to channel knowledge, share information, resources, and networks. This mechanism necessitates collaboration among various stakeholders, including industry, government, academia, and society (Quadruple Helix) [89]. However, Biggeri, Testi \& Bellucci warned that ecosystems can also hinder SEs in achieving their objectives and, more generally, in fostering social innovation [20].

Aside from internal elements that drive innovation, ecosystems are thought to be capable of shaping innovation. Several studies have found that a company's potential to innovate is hampered by a lack of financial access [90,91]. According to Chuluun, Prevost, and Upadhyay, diverse network characteristics influence the inputs and outputs of innovation [92]. Meanwhile, some studies claimed that network interactions between consumers, intermediaries, business groups, and providers of goods or services have an impact on innovation $[87,93]$. As previously said, numerous studies have shown that innovation has an impact on sustainability, they discovered that the key to a company's sustainability was its potential for innovation. Based on the previous research and the explanation above, the following research hypotheses are proposed [13-15,20]

Hypothesis 7 (H7). Innovation mediates the influence of internal factors on sustainability. 
Hypothesis 8 (H8). Innovation mediates the effect of ecosystems on sustainability.

\subsection{Mediation of Dynamic Capabilities and Innovation on Sustainability}

The mediating role of dynamic capabilities and innovation on sustainability does not stand alone. Dynamic capabilities that are well managed will create innovations which will then increase sustainability. Organizations need to be supported by the organization's ability to dynamically manage resources, namely integrating, building and reconfiguring internal and external competencies in the face of drastic environmental changes [94].

Research from Liao, Kickul, and Ma explored the ability to recognize opportunities and to configure and use existing resources (dynamic capabilities) in the company's innovation process [95]. In line with that, several other studies have also proven that dynamic capabilities affect innovation $[14,96,97]$. Meanwhile, other studies emphasized the importance of corporate resources on dynamic capabilities [17,98]. Rothaermel and Hess specifically emphasized three levels of internal resources that determine a company's innovation capability, namely the individual, company, and network levels as determinants of the company's innovation ability [98]. Although they did not explicitly define the existence of a dynamic capability construct, it is implied that this capability is formed due to the configuration of various resources owned by the company. Several recent studies have also found that resources and capacities can help drive innovation $[87,99]$. The ability to absorb plays a very important role in increasing the company's ability to create new knowledge that drives innovation. The Resource-Based-View also emphasized that resources and capabilities are important factors for companies to develop competitive advantages that ultimately drive innovation. The following hypotheses are proposed based on the findings of previous studies and the explanation provided.

Hypothesis 9 (H9). Dynamic capabilities and innovation mediate the influence of internal factors on sustainability.

Hypothesis 10 (H10). Dynamic capabilities and innovation mediate the influence of the ecosystem on sustainability.

The research model, as shown in Figure 1, is derived from the relationships between the variables stated in the hypotheses above.

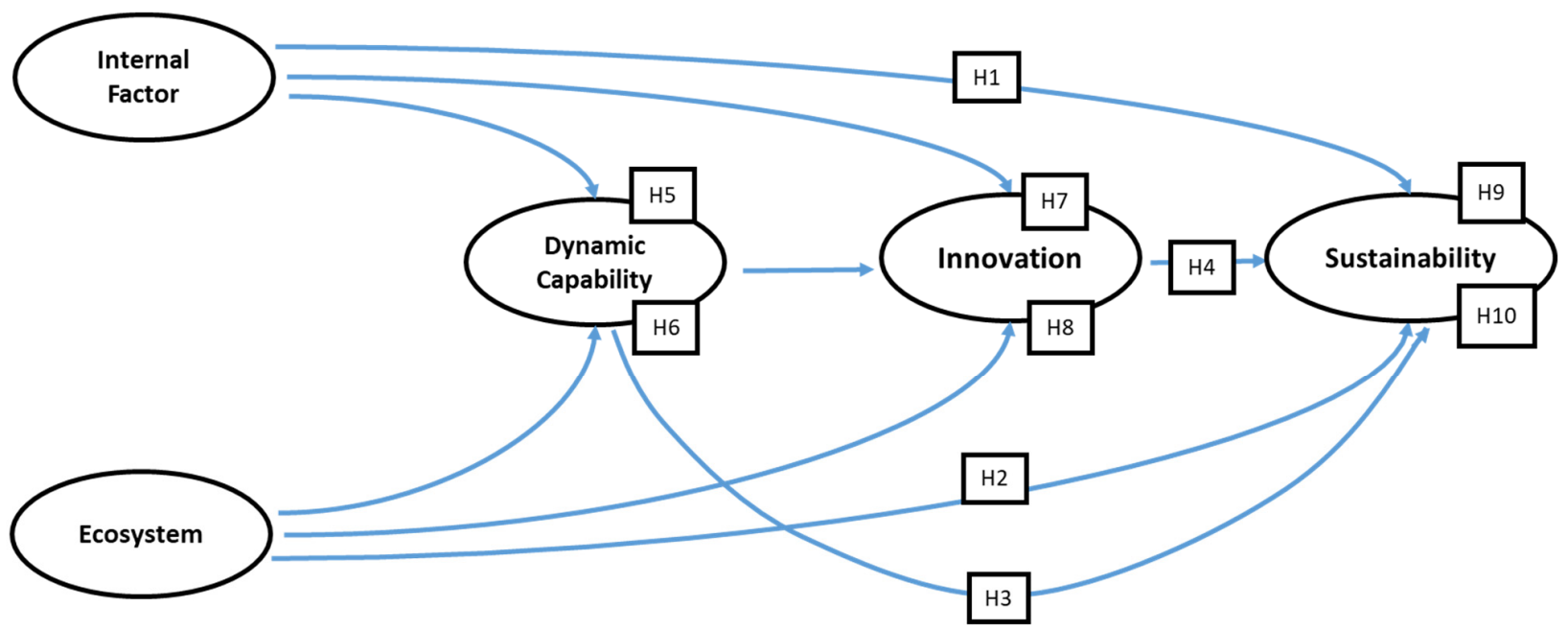

- The hypothesis attached to the arrow is a direct influence

- The hypothesis attached to the construct is a mediating role

Figure 1. Research Model. 


\section{Methods}

\subsection{Data Collection and Sampling}

Data collection was carried out through an online survey (SurveyMonkey platform) and some were conducted face-to-face during October 2020 to February 2021 in all regions in Indonesia. This study uses non-probability sampling or purposive sampling methods. The unit of research analysis is MSME, which is a social enterprise in Indonesia, and has been established for at least two years. Research respondents are the founders, owners, or managers who manage these MSMEs.

The sample measurement is based on Hair, Black, Babin, and Anderson's recommendation of a minimum sample size of 150 samples [100]. The sample of this study amounted to 187 respondents. This sample size is comparable with that in the previous research conducted by Puspadewi, Soetjipto, Wahyuni, and Wijayanto, which received responses from 189 social enterprises in Indonesia [101]. This research investigated the cognitive complexity of social enterprise leaders, which results in behavioral complexity and has an effect on sustainability performance.

Structural Equation Modeling (SEM) was used to analyze the data. SEM is made up of two analyses: the measurement model and the structural model. The measurement model quantifies the relationship between indicators and their latent variables, whereas the structural model explains the relationship between latent variables [102]. The validity and reliability of the model are assessed while evaluating the measurement model, while the level of fitness of the data with the model (via GOFI) and the significance of the coefficient of the variable being tested (through the t-value) are tested when testing the structural model.

\subsection{Instrument Development}

Five latent variables were measured in this study, namely sustainability, innovation, dynamic capabilities, internal factors, and ecosystem. Prospective respondents were asked screening questions to ensure that they met the requirements before filling out the questionnaire. The filter questions were: 1 . The organization has been in existence for over two years; 2 . All activities of the organization are not funded by grants; 3 . The primary goal is to carry out a social mission; 4 . The remaining operating profits are not only distributed to SE's shareholders.

The research questionnaire was designed to elicit responses to research questions from respondents. This study employed a six-point Likert scale, with 1 being 'strongly disagree' and 6 being 'strongly agree'. Each variable in this study was quantified using an indicator variable adapted from previous research. Table 1 summarizes the measurement model testing, as well as an example of an indicator for each dimension.

Table 1. Measurement Model Testing.

\begin{tabular}{|c|c|c|c|c|}
\hline Variables & Dimension & SLF & CR & $\begin{array}{c}\text { Sources } \\
\text { Modified From }\end{array}$ \\
\hline Sustainability & $\begin{array}{l}\text { Financial Sustainability ( } 3 \text { items) } \\
\text { - Our business revenues are sufficient } \\
\text { Non-financial Sustainability ( } 3 \text { items) } \\
\text { - Community development through empowering beneficiary }\end{array}$ & 0.73 & 0.78 & {$[12,103-106]$} \\
\hline Innovation & $\begin{array}{l}\text { Product Innovation (4 items) } \\
\text { - Number of new products/services introduced } \\
\text { Process Innovation ( } 3 \text { items) } \\
\text { - Pioneer disposition to introduce new process. }\end{array}$ & $\begin{array}{l}0.91 \\
0.98\end{array}$ & 0.93 & {$[67,70,107]$} \\
\hline
\end{tabular}


Table 1. Cont.

\begin{tabular}{|c|c|c|c|c|}
\hline Variables & Dimension & SLF & CR & $\begin{array}{c}\text { Sources } \\
\text { Modified From }\end{array}$ \\
\hline \multirow{10}{*}{ Dynamic Capability } & Marketing Innovation (3 items) & & & \\
\hline & $\begin{array}{l}\text { - Renewing the product promotion techniques employed for the } \\
\text { promotion }\end{array}$ & 0.90 & & \\
\hline & Sustainable Innovation (3 items) & & & \\
\hline & $\begin{array}{l}\text { - The activities of our organization do not pollute the } \\
\text { environment. }\end{array}$ & 0.93 & & \\
\hline & Open Innovation (3 items) & & & \\
\hline & - The community gives us the idea of innovating. & 0.51 & & \\
\hline & Sensing (3 items) & & & \\
\hline & $\begin{array}{l}\text { - We systematically search for information on the current market } \\
\text { situation }\end{array}$ & 0.84 & & \\
\hline & Seizing (3 items) & & & \\
\hline & $\begin{array}{l}\text { - We recognize what new information can be utilized in our } \\
\text { organization }\end{array}$ & 0.80 & 0.86 & [108] \\
\hline \multirow{5}{*}{ Internal Factors } & Transforming (3 items) & & & \\
\hline & $\begin{array}{l}\text { - In our organization, the change plan can be adapted to the } \\
\text { situation. }\end{array}$ & 0.82 & & \\
\hline & Mission (4 items) & & & \\
\hline & $\begin{array}{l}\text { - Since its beginning, our organization has sought to improve } \\
\text { society }\end{array}$ & 0.69 & 0.93 & [6] \\
\hline & $\begin{array}{l}\text { Leadership ( } 7 \text { items) } \\
\text { - Is passionate about his/her work }\end{array}$ & 0.82 & & [35] \\
\hline \multirow{6}{*}{ Ecosystem } & $\begin{array}{l}\text { Leader Personality (8 items) } \\
\text { - Quickly adapt when the business environment changes. }\end{array}$ & 0.82 & & {$[35,41]$} \\
\hline & $\begin{array}{l}\text { Company Resources(financial, human and social) (14 items) } \\
\text { - Our organization is easy to get loans from external parties }\end{array}$ & 1.02 & & {$[12,105,109-111]$} \\
\hline & Access to Finance (5 items) & & \multirow{4}{*}{0.74} & \\
\hline & - Many choices of sources of funds or loans in our area. & 0.53 & & {$[112,113]$} \\
\hline & $\begin{array}{l}\text { Access to Networks ( } 4 \text { items) } \\
\text { - There is a bond between institutions in the community and us }\end{array}$ & 0.75 & & {$[105,114]$} \\
\hline & $\begin{array}{l}\text { Social Culture ( } 5 \text { items) } \\
\text { • The local government rewards social enterprise's activities. }\end{array}$ & 0.80 & & {$[45,115]$} \\
\hline
\end{tabular}

\section{Results}

As shown in Table 2, the number of SEs is distributed evenly between those who do not have legal entities (sole proprietorship, 49.2\%) and those who do. The SE studied came from all over Indonesia, although the largest number (89.3\%) came from Java Island, according to the SE distribution map [116]. Respondents were dominated by micro-scale SE $(62.0 \%)$ with sales below Rp. 300 million per year, $27.3 \%$ small scale and $10.7 \%$ medium scale. Based on the number of employees, most (39.0\%) of SEs have less than 5 employees, and $29.4 \% 6$ to 10 people. Only $31.6 \%$ of SE have more than 10 employees. Most of the SEs have employees who are also beneficiaries (76.5\%) and only $23.5 \%$ of SEs whose employees are not beneficiaries.

In addition, based on the source of capital, the majority (56.7\%) of SE did not receive any grants at all. Most (84\%) of SE's capital did not come from loans to other parties (banks, non-banks, or moneylenders), and 51.3\% had the dominant capital composition (76-100\% of capital) coming from their own capital and family. Most SEs do two or three social activities. Poverty alleviation, education, and business empowerment are the top three social activities carried out by almost all social activities, both as primary and secondary activities. Similarly, in terms of business activities, SE does not have a single type of commercial activity. The trade and production sectors are the top two commercial activities carried out by SE, both as primary and secondary activities. The gender composition of respondents is balanced, with men $50.3 \%$ and women $49.7 \%$, and ages ranging from 25 to 40 years $(44.4 \%)$, followed by ages 41 to 56 years $(41.7 \%)$. This is consistent with the current 
population's demographics, which show that Gen X and Gen $Y$ are the most productive generations. In terms of education, the majority $(49.2 \%)$ have a bachelor's degree and a high school diploma (35.8\%). The majority of respondents $(72.7 \%)$ are owners or founders, with the remainder $(27.35 \%)$ are managers.

Table 2. Social Enterprise's profile.

\begin{tabular}{|c|c|c|}
\hline Category & Number of SE & Percentage \\
\hline \multicolumn{3}{|l|}{ 1. Legal Entity } \\
\hline Sole proprietorship & 92 & 49.2 \\
\hline Foundation & 46 & 24.6 \\
\hline Inc., Ltd. & 33 & 17.6 \\
\hline $\mathrm{CV}$ & 13 & 7.0 \\
\hline \multirow[t]{2}{*}{ Cooperation } & 3 & 1.6 \\
\hline & 187 & 100 \\
\hline \multicolumn{3}{|l|}{ 2. Area } \\
\hline West Java & 65 & 34.8 \\
\hline East Java & 31 & 16.6 \\
\hline Central Java & 29 & 15.5 \\
\hline Jakarta & 21 & 11.2 \\
\hline Bodetabek & 21 & 11.2 \\
\hline $\begin{array}{l}\text { Kalimantan, Sulawesi } \\
\text { and Papua }\end{array}$ & 9 & 4.8 \\
\hline Sumatra & 7 & 3.7 \\
\hline \multirow[t]{2}{*}{ Bali and Nusa Tenggara } & 4 & 2.1 \\
\hline & 187 & 100 \\
\hline \multicolumn{3}{|l|}{ 3. Annual Sales } \\
\hline$<\operatorname{Rp} 300$ Mio & 116 & 62.0 \\
\hline Rp 300 Mio-2.5 Bio & 51 & 27.3 \\
\hline \multirow[t]{2}{*}{ Rp 2.5 Bio-50 Bio } & 20 & 10.7 \\
\hline & 187 & 100 \\
\hline \multicolumn{3}{|l|}{ 4. Number of employees } \\
\hline$\leq 5$ & 73 & 39.0 \\
\hline$\overline{6}-10$ & 55 & 29.4 \\
\hline $11-20$ & 34 & 18.2 \\
\hline \multirow[t]{2}{*}{$>20$} & 25 & 13.4 \\
\hline & 187 & 100 \\
\hline \multicolumn{3}{|l|}{$\begin{array}{l}\text { 5. Employees concurrently } \\
\text { beneficiaries }\end{array}$} \\
\hline Yes & 143 & 76.5 \\
\hline \multirow[t]{2}{*}{ No } & 44 & 23.5 \\
\hline & 187 & 100 \\
\hline
\end{tabular}

\subsection{Measurement Model}

From the results of the validity test, two indicators of sustainability, two indicators of innovation, four indicators of internal factor, and four indicators of ecosystem have a standard factor loading (SFL) value of $<0.5$, so they are excluded from the model. The results of the latent variable reliability test show that the value of construct reliability $(\mathrm{CR})>0.7$ and the value of variance extract $(\mathrm{VE})>0.5$, except for construct sustainability (CR value is 0.78 ), so even though the VE is 0.47 (close to 0.5 ), it is still acceptable and categorized as acceptable [102,117]. Thus, all variables are declared valid and reliable.

\subsection{Structural Model}

Construction model testing was conducted to validate the proposed research model. The test results show the goodness of fit index consisting of RMSEA $=0.00 ; \mathrm{SRMR}=0.042$; 
$\mathrm{RMR}=0.028 ; \mathrm{GFI}=0.99 ; \mathrm{AGFI}=0.99 ; \mathrm{NFI}=1.00 ; \mathrm{NNFI}=1.02 ; \mathrm{RFI}=1.00$ and Normed Chi-square $=0.12$ all have a good fit. It can be said that the overall model fit of the structural model is good and the research data fit the model.

Figure 2 shows the research model with the results of hypothesis testing. Furthermore, an analysis of the structural relationship is performed. The t-value and coefficient on the structural equation are used to test the research hypothesis. If the variable has a $t$-value greater than 1.645, it is declared to have a significant effect (one-tailed). Table 3 displays the coefficients, the significance of the relationship between the direct variables, and the role of the mediating variable as calculated by the Sobel test.

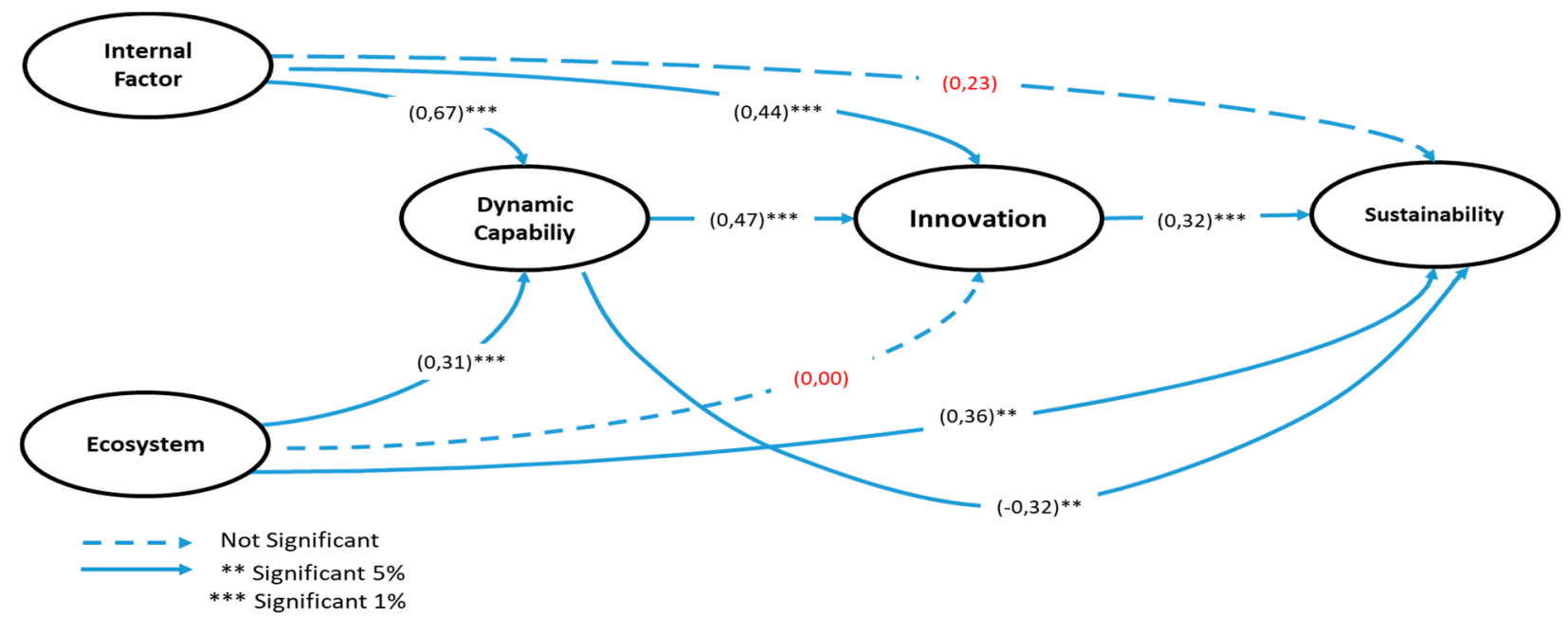

Figure 2. Research Result Model.

Table 3. Statistical Test Results: Structural model decomposition.

\begin{tabular}{|c|c|c|c|c|}
\hline Hypo-thesis & $\begin{array}{c}\text { Relationship between } \\
\text { Variables }\end{array}$ & Coefficient & \multicolumn{2}{|c|}{ Result } \\
\hline \multicolumn{5}{|c|}{ Direct Effect } \\
\hline $\mathrm{H} 1$ & $\begin{array}{l}\text { Internal factor to } \\
\text { sustainability }\end{array}$ & 0.23 & Not significant & $\begin{array}{l}\text { Hypothesis is not } \\
\text { supported }\end{array}$ \\
\hline $\mathrm{H} 2$ & $\begin{array}{l}\text { Ecosystem to } \\
\text { sustainability }\end{array}$ & $0.36^{* *}$ & Significant positive & $\begin{array}{l}\text { Hypothesis is } \\
\text { supported }\end{array}$ \\
\hline $\mathrm{H} 3$ & $\begin{array}{l}\text { Dynamic capability } \\
\text { to sustainability }\end{array}$ & $-0.32^{* *}$ & Significant negative & $\begin{array}{l}\text { Hypothesis is not } \\
\text { supported }\end{array}$ \\
\hline $\mathrm{H} 4$ & $\begin{array}{l}\text { Innovation to } \\
\text { sustainability }\end{array}$ & $0.32^{* * *}$ & Significant positive & $\begin{array}{l}\text { Hypothesis is } \\
\text { supported }\end{array}$ \\
\hline \multicolumn{5}{|c|}{ Mediation Role of Dynamic Capability } \\
\hline H5 & $\begin{array}{l}\text { Internal factor to } \\
\text { sustainability }\end{array}$ & $0.67 x-0.32=-0.21$ & Not significant & $\begin{array}{l}\text { Hypothesis is not } \\
\text { supported }\end{array}$ \\
\hline H6 & $\begin{array}{l}\text { Ecosystem to } \\
\text { sustainability }\end{array}$ & $0.31 x-0.32=-0.1$ & Not significant & $\begin{array}{l}\text { Hypothesis is not } \\
\text { supported }\end{array}$ \\
\hline \multicolumn{5}{|c|}{ Mediation Role of Innovation } \\
\hline $\mathrm{H} 7$ & $\begin{array}{l}\text { Internal factor to } \\
\text { sustainability }\end{array}$ & $0.44 \times 0.32=0.28^{* * *}$ & Significant positive & $\begin{array}{l}\text { Hypothesis is } \\
\text { supported }\end{array}$ \\
\hline $\mathrm{H} 8$ & $\begin{array}{l}\text { Ecosystem to } \\
\text { sustainability }\end{array}$ & $0.00 \times 0.32=0.00$ & Not significant & $\begin{array}{l}\text { Hypothesis is not } \\
\text { supported }\end{array}$ \\
\hline
\end{tabular}


Table 3. Cont.

\begin{tabular}{|c|c|c|c|c|}
\hline Hypo-thesis & $\begin{array}{c}\text { Relationship between } \\
\text { Variables }\end{array}$ & Coefficient & \multicolumn{2}{|c|}{ Result } \\
\hline \multicolumn{5}{|c|}{ Mediation Role of Dynamic Capability and Innovation } \\
\hline H9 & $\begin{array}{l}\text { Internal factor to } \\
\text { sustainability }\end{array}$ & $0.67 \times 0.47 \times 0.32=0.1^{* *}$ & Significant positive & $\begin{array}{l}\text { Hypothesis is } \\
\text { supported }\end{array}$ \\
\hline $\mathrm{H} 10$ & $\begin{array}{l}\text { Ecosystem to } \\
\text { sustainability }\end{array}$ & $0.31 \times 0.47 \times 0.32=0.05^{* *}$ & Significant positive & $\begin{array}{l}\text { Hypothesis is } \\
\text { supported }\end{array}$ \\
\hline
\end{tabular}
$5 \%$. ${ }^{* * *}$ significant $1 \%$.

It was discovered that the factors that directly influence SE's sustainability are ecosystems, dynamic capabilities, and innovation, while the factors that indirectly influence SE's sustainability are internal factors. Internal factors, with mediating variables dynamic capabilities and innovation, are the most effective way to influence SE's sustainability.

\section{Discussion, Implications, and Conclusions}

\subsection{Discussion}

The purpose of this research is to examine the factors that have a direct impact on SE's sustainability, as well as the role of dynamic capabilities and innovation in ensuring SE's sustainability. The findings of this study do not support the previous studies that found internal factors have direct impacts on sustainability $[27,34,36]$. This study shows that SE's mission, leadership, leader personality, and resources (financial, human, and social) are insufficient to ensure sustainability. Therefore, internal factors do not have a significant positive effect on sustainability.

This study attempts to clarify the ecosystem and dynamic capability theories. The ecosystem theory suggests that the environment has provided the elements required to construct mechanisms for innovation $[45,88,89]$. Thus, it is up to any enterprise within the ecosystem to utilize the mechanisms and resources available within the ecosystem. Meanwhile, dynamic capability theory asserts that resources alone are insufficient to create innovation. The findings of this study point out social enterprises should equip themselves with the ability to capture what is happening in the ecosystem and combine it with internal resources to innovate. According to the literature, this innovation should be collaborative.

Furthermore, this study also demonstrates that the ecosystem has a significant positive effect on SE's sustainability. This is consistent with previous research [12,30,48,51,52], which discovered that access to finance and networks, as well as the role of social culture, all contribute to SE's sustainability. This study particularly reveals that social culture and access to networks play an important role as shown by the finding that SE activists are motivated by the community's encouragement and appreciation.

In contrast with the findings of Ince and Hahn [62], who found that SE sustainability will be aided by dynamic capabilities, this study shows a negative relationship which can be explained as follows: first and foremost, it must be acknowledged that developing organizational capabilities that are constantly adaptable to changes in the environment is extremely difficult [118]. Even if it is technically possible, dynamic capabilities like this have the potential to reduce SE's sustainability. This is due to the fact that the characteristics of SE are not always the same as those of SMEs that only carry out commercial activities and want to continue to change in response to changes in the environment to maintain their competitive advantage. In the case of SE, too dynamic (radical) changes can jeopardize the organization's sustainability because they consume resources; thus, not surprisingly, dynamic capabilities have a negative impact $[119,120]$. This is reinforced by SE in this study majority (62\%) are micro-scale MSMEs with annual sales of less than Rp 300 million. Changes that are too frequent and necessitate relatively large costs (for example, changing machines, SOPs, layouts, or others) will have a significant impact on the company's finances and, ultimately, its sustainability. 
The impact of innovation on sustainability is significant. This is consistent with the findings of previous research $[13,14,20]$, which showed that innovation has a significant impact on sustainability. The dimensions of process innovation, sustainability innovation, product innovation, and marketing innovation strongly shape the innovation. In practice, SE must continue to innovate to meet market demands. Nonetheless, the innovations implemented must remain consistent with SE's mission and primary goals. Several SEs with social activities focused on poverty alleviation and women's empowerment want to help the surrounding community prosper by teaching mothers and young women in the SE environment to sew blankets and bags out of patchwork. SE saw new business opportunities as a result of the pandemic, sewing masks, prayer mats for traveling, and even hats with a face shield. This solution may not be long-term, but to survive, SE must be able to produce short-term innovations.

Dynamic capabilities do not mediate the influence of internal and ecosystem factors on SE sustainability. Nonetheless, this study demonstrates that innovation mediates internal factors to sustainability; innovation plays a role in absorbing internal factors to build sustainability. This is consistent with previous that found that internal factors create innovation $[16,17,19,85]$, and that innovation, in turn, increases sustainability $[13,14,20]$. Leaders or owners of SEs need to continuously create opportunities to ensure their sustainability that would help the beneficiaries.

Dynamic capabilities and innovation, when combined, mediate internal and ecosystem factors to SE sustainability. This is consistent with previous research $[14,96,97]$ that found dynamic capabilities will encourage innovation and eventually sustainability. Although dynamic capabilities do not mitigate the impact of internal and ecosystem factors on SE sustainability, they will increase SE sustainability if they are used to foster innovation through product changes, work methods, promotions, or other small (incremental) changes.

Earlier studies on ecosystem theory imply that firms and their ecosystems have a reciprocal relationship [45]. Various elements of the ecosystem can facilitate or hinder business continuity, and firms' activities or conduct would have an impact on the ecosystem's quality or even sustainability. To capture this relationship, the research develops various indicators to determine how far the company is giving back to the business environment or ecosystem, in addition to examining the various factors that influence the sustainability of social enterprises, which is the main purpose of this study. "Our company establishes a new $\mathrm{SE}$," "our organization motivates people to care about social enterprise," "our organization is involved in the social enterprise community," and "there is a bond between institutions in the community and us" were among the indicators examined.

Most of the indicators used (with loading levels above 50\%) confirm that the firm delivers something back to its ecosystem. This is strong evidence that social enterprises have contributed to the development of broad social awareness in the community, which will ultimately strengthen the ecosystem. However, the indicator for "developing new SE" is low, implying that SE in Indonesia has not yet fully contributed to the growth of new enterprises of the same kind (scale-up).

\subsection{Implications}

This study demonstrates that the ecosystem is a difficult factor for the SE to control, but it can determine the SE's life or death. For example, if the culture of the community has been absorbed through various social activities, the sustainability of the SE can be expected; however, the opposite situation can also occur. Faced with this, SE does not have to surrender to circumstances in the external environment over which he has no control. Through their dynamic capabilities, SE management must learn to manage changes in the external environment (ecosystem). Therefore, SE needs to adapt to the ecosystem that can affect sustainability. SE needs to understand changes in the environment and strive to attract support from the surrounding community. SE assisted by the local government can socialize the importance of the existence of SE to the local community and open themselves 
to opportunities or changes that exist. What needs to be considered is the adaptation that is made as much as possible does not change the SE mission.

On the other hand, management must recognize that SE's internal resources are insufficient to ensure the sustainability of SE. It requires the ability to recognize and seize opportunities, as well as to filter which ones are important to the organization and rearrange internal resources to deal with them. SE needs to increase the flexibility of its resources in order to create innovation and improve sustainability. SE should make its employees more generalist in order to be more adaptive to change. SE should also not be fixated on rigid programs when making financial budgets and be more active in SE activities that support its mission.

However, SE management must exercise caution when developing dynamic capabilities to support its sustainability. The ability to identify and capitalize on existing opportunities, followed by too radical changes, will actually reduce SE's sustainability. SE managers need to be careful in choosing the right strategy when adapting to environmental changes. If the environment changes so drastically, it is better for SE managers to concentrate on preparing HR so that they can work more flexibly, but do not need to make drastic changes to the organization, SOPs and others (which characterize dynamic capabilities). SE's innovation should be in the form of incremental change, not radical change. SE does not need to force innovation on radical change. SE should perform a collaborative innovation, utilizing resources and infrastructures that available in ecosystem. This innovation should be in the form of incremental change, not radical change. SE does not need to force innovation on radical change. SE can multiply creative ideas to make product diversification, marketing channels, promotions and more.

\subsection{Limitation and Future Research Suggestions}

This article provides empirical evidence on the importance of innovation and dynamic capability in ensuring the sustainability of a society. However, some limitations must be considered. The study's first limitation is the relatively small sample size. Despite the fact that it has covered all of Indonesia, the number of samples is still very small. If this study is to be replicated in other countries, the research sample should be expanded. This study was carried out on the MSE scale SE; the results may differ when applied to a larger scale SE. Similarly, if applied outside of Indonesia, which has a different organizational culture and the role of the private sector or the government may be very different, it is necessary to exercise extreme caution in generalizing the study's findings. In addition, more research into more appropriate government support for SEs is required. The following research can include infrastructure variables that support innovation, as well as an examination of SE based on the type of activity, which may yield different results. Furthermore, the perspectives of employees and beneficiaries were not taken-into account in this study. As a result, future research should include the perspectives of employees and beneficiaries to validate the study's findings.

\subsection{Conclusions}

Ecosystems, dynamic capabilities and innovation are proven to have a direct effect on sustainability, while internal factors must be managed properly before they can affect the sustainability of SE. Ecosystems have a significant positive direct effect on the sustainability of SE; meaning that changes in the ecosystem can determine the life/death of SE. An interesting finding in this study is that dynamic capabilities have a significant but negative direct effect on SE sustainability. The higher the dynamic capability can endanger the sustainability of SE. Innovation is proven to have a significant positive effect on sustainability.

The role of dynamic capabilities as a mediator from internal and ecosystem factors to SE sustainability is not proven. The management of internal factors and ecosystems is not enough to make SE able to continue its business. However, innovation is proven to play a role as a mediator in the influence of internal factors on sustainability. If internal factors 
succeed in creating innovation, then business sustainability will be higher. However, the role of innovation to mediate ecosystem effects is not proven. The joint role of capability and innovation as a mediator in the influence of internal and ecosystem factors to increase SE sustainability has proven to be significantly positive. When internal factors can be absorbed by dynamic capabilities and create innovation, SE sustainability will increase. It's the same with ecosystems, if SE's dynamic capabilities are able to absorb the ecosystem and then create innovations, SE will be able to increase the sustainability of its business.

Ecosystems, dynamic capabilities, and innovation have been shown to have a direct impact on sustainability, whereas internal factors must be managed properly before they can have an impact on SE's sustainability. Ecosystems have a significant positive direct effect on SE's sustainability, which means that changes in the ecosystem can determine SE's life/death. This study discovered an intriguing finding: dynamic capabilities have a significant but negative direct effect on SE sustainability. The greater the dynamic capability, the greater the risk to SE's sustainability; however, innovation has been shown to have a significant positive effect on sustainability.

The role of dynamic capabilities as a mediator between internal and ecosystem factors and socioeconomic sustainability has not been established. The management of internal factors and ecosystems is insufficient to allow SE to continue operations. However, it has been demonstrated that innovation can act as a mediator in the influence of internal factors on sustainability. If internal factors succeed in generating innovation, business sustainability will improve. However, the role of innovation in mediating ecosystem effects has yet to be established. The combined role of capability and innovation as a mediator in the influence of internal and ecosystem factors on SE sustainability has proven to be extremely beneficial. SE sustainability will increase when internal factors can be absorbed by dynamic capabilities and generate innovation. It is the same with ecosystems; if SE's dynamic capabilities can absorb the ecosystem and then create innovations, SE will be able to increase its business's sustainability.

Author Contributions: Conceptualization, P.M.D.; supervision: M.S.M.; methodology, P.M.D. and H.P.; validation, R.P., M.N.; formal analysis, P.M.D.; investigation, P.M.D.; data curation, P.M.D.; writing—original draft preparation, P.M.D.; writing—review and editing, all.; visualization, P.M.D.; proofread, R.R.; project administration, P.M.D. All authors have read and agreed to the published version of the manuscript.

Funding: This research is partially funded by Faculty of Economics and Business Universitas Indonesia, No: SK-378/UN2.F6.D/HKP.02.04/2021.

Institutional Review Board Statement: Not applicable.

Informed Consent Statement: Not applicable.

Data Availability Statement: Not applicable.

Conflicts of Interest: The authors declare no conflict of interest.

\section{References}

1. Bidet, E.; Defourny, J. Social Enterprise in Asia: Theory, Models and Practice, 1st ed.; Bidet, E., Defourny, J., Eds.; Routledge: New York, NY, USA, 2019; ISBN 9780429265761.

2. Dacin, M.T.; Dacin, P.A.; Tracey, P. Social entrepreneurship: A critique and future directions. Organ. Sci. 2011, 22, 1203-1213. [CrossRef]

3. Santos, F.M. A positive theory of social entrepreneurship. J. Bus. Ethic. 2012, 111, 335-351. [CrossRef]

4. Martínez-Climent, C.; Rodríguez-García, M.; Zeng, J. Ambidextrous leadership, social entrepreneurial orientation, and operational performance. Sustainability 2019, 11, 890. [CrossRef]

5. Huybrechts, B.; Nicholls, A. Social entrepreneurship: Definitions, drivers and challenges. In Social Entrepreneurship and Social Business: An Introduction and Discussion with Case Studies; Springer Gabler: Wiesbade, Germany, 2012; pp. 31-48.

6. Stevens, R.; Moray, N.; Bruneel, J.; Clarysse, B. Attention allocation to multiple goals: The case of for-profit social enterprises. Strat. Manag. J. 2015, 36, 1006-1016. [CrossRef]

7. Leung, S.; Mo, P.; Ling, H.; Chandra, Y.; Ho, S.S. Enhancing the competitiveness and sustainability of social enterprises in Hong Kong: A three-dimensional analysis. China J. Account. Res. 2019, 12, 157-176. [CrossRef] 
8. Lee, H. The Role of Relationships in Building Capabilities for Social Innovation: The Case of Social Enterprises. 2015. Available online: https:/ / uwe-repository.worktribe.com/output/806756/the-role-of-relationships-in-building-capabilities-for-socialinnovation-the-case-of-social-enterprises (accessed on 3 April 2020).

9. ESCAP. British Council and United Nations ESCAP Launch Landmark Indonesia Social Enterprise Landscape Study. 2018. Available online: https://www.unescap.org/news/british-council-and-united-nations-escap-launch-landmark-indonesia-socialenterprise-landscape (accessed on 4 May 2020).

10. André, K.; Pache, A.-C. From caring entrepreneur to caring enterprise: Addressing the ethical challenges of scaling up social enterprises. J. Bus. Ethic. 2016, 133, 659-675. [CrossRef]

11. Ruskin, J.; Seymour, R.G.; Webster, C.M. Why create value for others? An exploration of social entrepreneurial motives. J. Small Bus. Manag. 2016, 54, 1015-1037. [CrossRef]

12. Sabella, A.R.; Eid, N.L. A strategic perspective of social enterprise sustainability. J. Gen. Manag. 2016, 41, 71-89. [CrossRef]

13. Carayannis, E.G.; Grigoroudis, E.; Sindakis, S.; Walter, C. Business model innovation as antecedent of sustainable enterprise excellence and resilience. J. Knowl. Econ. 2014, 5, 440-463. [CrossRef]

14. Konys, A. Towards sustainable entrepreneurship holistic construct. Sustainability 2019, 11, 6749. [CrossRef]

15. Osburg, T. Social innovation to drive corporate sustainability. In Social Innovation; Osburg, T., Schmidpeter, R., Eds.; Springer: Berlin/Heidelberg, Germany, 2013; pp. 13-22.

16. Bagheri, A. The impact of entrepreneurial leadership on innovation work behavior and opportunity recognition in high-technology SMEs. J. High Technol. Manag. Res. 2017, 28, 159-166. [CrossRef]

17. Xiaojing, W. Firm resources and dynamic capability promotion: An empirical study. In Proceedings of the 2009 International Conference on Information Management, Innovation Management and Industrial Engineering, Xi'an, China, 26-27 December 2009; IEEE: New York, NY, USA, 2009; Volume 2, pp. 118-121.

18. Pasricha, P.; Rao, M.K. The effect of ethical leadership on employee social innovation tendency in social enterprises: Mediating role of perceived social capital. Creat. Innov. Manag. 2018, 27, 270-280. [CrossRef]

19. Unsworth, K.L.; Parker, S.K. Proactivity and innovation: Promoting a new workforce for the new workplace. In The New Workplace: A Guide to the Human Impact of Modern Working Practices; Holman, D., Wall, T.D., Clegg, C.W., Sparrow, P., Howard, A., Eds.; John Wiley \& Sons: Chichester, UK, 2003; pp. 175-196.

20. Biggeri, M.; Testi, E.; Bellucci, M. Enabling ecosystems for social enterprises and social innovation: A capability approach perspective. J. Hum. Dev. Capab. 2017, 18, 299-306. [CrossRef]

21. Han, J.; Shah, S. The ecosystem of scaling social impact: A new theoretical framework and two case studies. J. Soc. Entrep. 2020, 11, 215-239. [CrossRef]

22. Teece, D.J.; Pisano, G.; Shuen, A. Dynamic capabilities and strategic management. Strateg. Manag. J. 1997, 18, 509-533. [CrossRef]

23. Doherty, B.; Haugh, H.; Lyon, F. Social enterprises as hybrid organizations: A review and research agenda. Int. J. Manag. Rev. 2014, 16, 417-436. [CrossRef]

24. Powell, M.; Gillett, A.; Doherty, B. Sustainability in social enterprise: Hybrid organizing in public services. Public Manag. Rev. 2019, 21, 159-186. [CrossRef]

25. Moore, J. Seven recommendations for creating sustainability education at the university level. Int. J. Sustain. High. Educ. 2005, 6, 326-339. [CrossRef]

26. Reficco, E.; Layrisse, F.; Barrios, A. From donation-based NPO to social enterprise: A journey of transformation through business-model innovation. J. Bus. Res. 2020, 125, 720-732. [CrossRef]

27. Aleixo, A.M.; Leal, S.; Azeiteiro, U.M. Conceptualizations of sustainability in Portuguese higher education: Roles, barriers and challenges toward sustainability. J. Clean. Prod. 2018, 172, 1664-1673. [CrossRef]

28. Okorley, E.L.; Nkrumah, E.E. Organisational factors influencing sustainability of local non-governmental organisations. Int. J. Soc. Econ. 2012, 39, 330-341. [CrossRef]

29. Sabadie, J.A. Technological innovation, human capital and social change for sustainability. Lessons learnt from the industrial technologies theme of the EU's research framework programme. Sci. Total Environ. 2014, 481, 668-673. [CrossRef] [PubMed]

30. Sigasa, M. Factors That Influence the Sustainability of Social Enterprises as Hybrid Organisation. Ph.D. Thesis, University of Pretoria, Pretoria, South Africa, 2015. Available online: http:/ / hdl.handle.net/2263/44457 (accessed on 11 April 2020).

31. Bart, C.K. The Impact of mission on firm innovativeness. Int. J. Technol. Manag. 1996, 11, 479-493. [CrossRef]

32. Bart, C.K.; Bontis, N.; Taggar, S. A model of the impact of mission statements on firm performance. Manag. Decis. 2001, 39, 19-35. [CrossRef]

33. Perrini, F.; Vurro, C. Social entrepreneurship: Innovation and social change across theory and practice. In Social Entrepreneurship; Mair, J., Robinson, J., Hockerts, K., Eds.; Palgrave Macmillan: London, UK, 2006; pp. 57-85.

34. Marshall, J.; Coleman, G.; Reason, P. Leadership for Sustainability: An Action Research Approach, 1st ed.; Routledge: New York, NY, USA, 2017; ISBN 9781906093594.

35. Renko, M.; El Tarabishy, A.; Carsrud, A.L.; Brännback, M. Understanding and measuring entrepreneurial leadership style. J. Small Bus. Manag. 2015, 53, 54-74. [CrossRef]

36. Murphy, G.; Tocher, N.; Burch, T. Small business owner persistence: Do personal characteristics matter? J. Small Bus. Strategy 2019, 29, 99-114. 
37. Robbins, S.P.; Judge, T.A. Organizational Behavior Global Edition, 17th ed.; Pearson Education Limited: London, UK, 2017; ISBN 9780134103983.

38. Aldrich, H.E.; Zimmer, C. The Art and Science of Entrepreneurship, 1st ed.; Ballinger: Cambridge, MA, USA, 1986; pp. 3-23 ISBN 9780887300707

39. Salleh, F.; Ibrahim, M.D. Demographic characteristics differences of risk-taking propensity among micro and small business owners in Malaysia. Int. J. Bus. Soc. Sci. 2011, 2, 149-153.

40. Chipeta, E.M.; Surujlal, J. Influence of attitude, risk taking propensity and proactive personality on social entrepreneurship intentions. Pol. J. Manag. Stud. 2017, 15, 27-36. [CrossRef]

41. Crant, J.M. Proactive behavior in organizations. J. Manag. 2000, 26, 435-462. [CrossRef]

42. Isenberg, D.J. The Big Idea: How to Start an Entrepreneurial Revolution-Harvard Business Review. 2010. Available online: https: / / hbr.org/2010/06/the-big-idea-how-to-start-an-entrepreneurial-revolution (accessed on 21 April 2020).

43. Kansheba, J.M.P.; Wald, A.E. Entrepreneurial ecosystems: A systematic literature review and research agenda. J. Small Bus. Enterp. Dev. 2020, 27, 943-964. [CrossRef]

44. Philip, R. "Small town" entrepreneurial ecosystems. J. Entrep. Emerg. Econ. 2017, 9, 238-262.

45. Stam, F.C.; Spigel, B. Entrepreneurial ecosystems. USE Discuss. Pap. Ser. 2016, 16. Available online: https://dspace.library.uu.nl/ handle/1874/347982 (accessed on 25 December 2021).

46. Venkataraman, S. Regional transformation through technological entrepreneurship. J. Bus. Ventur. 2004, 19, 153-167. [CrossRef]

47. Theodoraki, C.; Messeghem, K.; Rice, M.P. A social capital approach to the development of sustainable entrepreneurial ecosystems: An explorative study. Small Bus. Econ. 2018, 51, 153-170. [CrossRef]

48. Di Zhang, D.; Swanson, L.A. Linking social entrepreneurship and sustainability. J. Soc. Entrep. 2014, 5, 175-191. [CrossRef]

49. Czischke, D.; Gruis, V.; Mullins, D. Conceptualising social enterprise in housing organisations. Hous. Stud. 2012, $27,418-437$. [CrossRef]

50. Fernandez, R.M.; Castilla, E.J.; Moore, P. Social capital at work: Networks and employment at a phone center. Am. J. Sociol. 2000, 105, 1288-1356. [CrossRef]

51. Kahle, J.; Risch, K.; Wanke, A.; Lang, D.J. Strategic networking for sustainability: Lessons learned from two case studies in higher education. Sustainability 2018, 10, 4646. [CrossRef]

52. Fang, H. Social culture and economic performance. Am. Econ. Rev. 2001, 91, 924-937. [CrossRef]

53. Feld, B. Startup Communities: Building an Entrepreneurial Ecosystem in Your City, 2nd ed.; Wiley: New York, NY, USA, 2012; ISBN 9781119204459.

54. Thai, M.T.T.; Turkina, E. Macro-level determinants of formal entrepreneurship versus informal entrepreneurship. J. Bus. Ventur. 2014, 29, 490-510. [CrossRef]

55. Teece, D.J. Explicating dynamic capabilities: The nature and microfoundations of (sustainable) enterprise performance. Strat. Manag. J. 2007, 28, 1319-1350. [CrossRef]

56. Helfat, C.E.; Peteraf, M.A. Understanding dynamic capabilities: Progress along a developmental path. Strat. Organ. 2009, 7, 91-102. [CrossRef]

57. Eisenhardt, K.M.; Martin, J.A. Dynamic capabilities: What are they? Strateg. Manag. J. 2000, 21, 1105-1121. [CrossRef]

58. Wu, L.-Y. Entrepreneurial resources, dynamic capabilities and start-up performance of Taiwan's high-tech firms. J. Bus. Res. 2007, 60, 549-555. [CrossRef]

59. Pavlou, P.A.; El Sawy, O.A. Understanding the elusive black box of dynamic capabilities. Decis. Sci. 2011, 42, 239-273. [CrossRef]

60. Zollo, M.; Winter, S.G. Deliberate learning and the evolution of dynamic capabilities. Organ. Sci. 2002, 13, 339-351. [CrossRef]

61. Eikelenboom, M.; de Jong, G. The impact of dynamic capabilities on the sustainability performance of SMEs. J. Clean. Prod. 2019, 235, 1360-1370. [CrossRef]

62. Ince, I.; Hahn, R. How dynamic capabilities facilitate the survivability of social enterprises: A qualitative analysis of sensing and seizing capacities. J. Small Bus. Manag. 2018, 58, 1256-1290. [CrossRef]

63. Roos, G.; O'Connor, A. The idea of integrating innovation: Entrepreneurship and a systems perspective. In Integrating Innovation: South Australian Entrepreneurship Systems and Strategies; University of Adelaide Press: Adelaide, Australia, 2015; pp. 3-32.

64. The Young Foundation. Social Innovation Overview: Part I-Defining Social Innovation. Deliverable to the Project "The Theoretical, Empirical and Policy Foundations for Building Social Innovation in Europe". 2012. Available online: https: / / issuu.com/youngfoundation/docs/tepsie.d1.1.report.definingsocialinnovation.part_1 (accessed on 20 March 2020).

65. Crossan, M.M.; Apaydin, M. A Multi-dimensional framework of organizational innovation: A systematic review of the literature: A framework of organizational innovation. J. Manag. Stud. 2010, 47, 1154-1191. [CrossRef]

66. Lumpkin, G.T.; Dess, G.G. Clarifying the entrepreneurial orientation construct and linking It to performance. Acad. Manag. Rev. 1996, 21, 135-172. [CrossRef]

67. Gunday, G.; Ulusoy, G.; Kilic, K.; Alpkan, L. Effects of innovation types on firm performance. Int. J. Prod. Econ. 2011, 133, 662-676. [CrossRef]

68. OECD. Statistical Office of the European Communities. Oslo Manual: Guidelines for Collecting and Interpreting Innovation Data; OECD Publishing: Paris, France, 2005; ISBN 9264013083.

69. Tidd, J.; Bessant, J.; Pavitt, K. Managing Innovation: Integrating Technological, Market, and Organizational Change, 3rd ed.; Wiley \& Sons: Hoboken, NJ, USA, 2005; ISBN 978-0470093269. 
70. Fontana, A.; Musa, S. The impact of entrepreneurial leadership on innovation management and its measurement validation. Int. J. Innov. Sci. 2017, 9, 2-19. [CrossRef]

71. Najib, M.; Rahman, A.A.A.; Abror, A.; Rachmawati, R.; Simanjuntak, M.; Prasetya, P.; Suhartanto, D.; Fahma, F. Leaders' support of sustainable innovation and business sustainability in developing countries: Evidence from small and medium food processing enterprises. Sustainability 2021, 13, 13091. [CrossRef]

72. Bennett, N.; Lemoine, G.J. What a difference a word makes: Understanding threats to performance in a VUCA world. Bus. Horiz. 2014, 57, 311-317. [CrossRef]

73. Schoemaker, P.J.H.; Heaton, S.; Teece, D. Innovation, dynamic capabilities, and leadership. Calif. Manag. Rev. 2018, 61, 15-42. [CrossRef]

74. McKelvie, A.; Davidsson, P. From resource base to dynamic capabilities: An investigation of new firms. Br. J. Manag. 2009, 20, S63-S80. [CrossRef]

75. Arend, R.J. Entrepreneurship and dynamic capabilities: How firm age and size affect the "capability enhancement-SME performance" relationship. Small Bus. Econ. 2013, 42, 33-57. [CrossRef]

76. Stadler, C.; Helfat, C.E.; Verona, G. The impact of dynamic capabilities on resource access and development. Organ. Sci. 2013, 24, 1782-1804. [CrossRef]

77. Eriksson, T. Processes, antecedents and outcomes of dynamic capabilities. Scand. J. Manag. 2014, 30, 65-82. [CrossRef]

78. MacPherson, A.; Herbane, B.; Jones, O. Developing dynamic capabilities through resource accretion: Expanding the entrepreneurial solution space. Entrep. Reg. Dev. 2015, 27, 259-291. [CrossRef]

79. Ali, A. Leadership and its influence in organizations-A review of intellections. Int. J. Learn. Dev. 2012, 2, 73. [CrossRef]

80. Avolio, B.J.; Bass, B.M.; Jung, D.I. Re-examining the components of transformational and transactional leadership using the multifactor leadership. J. Occup. Organ. Psychol. 1999, 72, 441-462. [CrossRef]

81. Haque, A.U.; Yamoah, F.A. The role of ethical leadership in managing occupational stress to promote innovative work behaviour: A cross-cultural management perspective. Sustainability 2021, 13, 9608. [CrossRef]

82. Koryak, O.; Mole, K.F.; Lockett, A.; Hayton, J.C.; Ucbasaran, D.; Hodgkinson, G.P. Entrepreneurial leadership, capabilities and firm growth. Int. Small Bus. J. Res. Entrep. 2015, 33, 89-105. [CrossRef]

83. Iddris, F. Innovation capability: A systematic review and research agenda. Interdiscip. J. Inf. Knowl. Manag. 2016, 11, 235-260. [CrossRef]

84. Prasad, B.; Junni, P. CEO transformational and transactional leadership and organizational innovation. Manag. Decis. 2016, 54, 1542-1568. [CrossRef]

85. Li, C.; Makhdoom, H.U.R.; Asim, S. Impact of entrepreneurial leadership on innovative work behavior: Examining mediation and moderation mechanisms. Psychol. Res. Behav. Manag. 2020, 13, 105-118. [CrossRef]

86. Hossain, U.; Al Asheq, A. Do leadership orientation and proactive personality influence social entrepreneurial intention. Int. J. Manag. Enterp. Dev. 2020, 19, 109-125. [CrossRef]

87. Choi, E.; Kim, E.; Kim, I.; Choi, I. Attitude toward social enterprises: A comparison between for-profit and social enterprise employees. Sustainability 2020, 12, 2720. [CrossRef]

88. Igwe, P.A.; Odunukan, K.; Rahman, M.; Rugara, D.G.; Ochinanwata, C. How entrepreneurship ecosystem influences the development of frugal innovation and informal entrepreneurship. Thunderbird Int. Bus. Rev. 2020, 62, 475-488. [CrossRef]

89. Valackienè, A.; Nagaj, R. Shared taxonomy for the implementation of responsible innovation approach in industrial ecosystems. Sustainability 2021, 13, 9901. [CrossRef]

90. Cincera, M.; Santos, A. Innovation and access to finance. IRMO Occasional Papers. 2015. Available online: http://www.solvay. edu/sites/upload/files/WP016-2015-4.pdf (accessed on 29 December 2020).

91. Khan, S.U.; Shah, A.; Rizwan, M.F. Do financing constraints matter for technological and non-technological innovation? A (re)examination of developing markets. Emerg. Mark. Financ. Trade 2019, 57, 2739-2766. [CrossRef]

92. Chuluun, T.; Prevost, A.; Upadhyay, A. Firm network structure and innovation. J. Corp. Financ. 2017, 44, 193-214. [CrossRef]

93. Pittaway, L.; Robertson, M.; Munir, K.; Denyer, D.; Neely, A.D. Networking and innovation: A systematic review of the evidence. Int. J. Manag. Rev. 2004, 5-6, 137-168. [CrossRef]

94. Teece, D.; Pisano, G. The dynamic capabilities of firms: An introduction. In Handbook on Knowledge Management; Holsapple, C.W., Ed.; Springer: Berlin, Germany, 2003; pp. 195-213.

95. Liao, J.; Kickul, J.R.; Ma, H. Organizational dynamic capability and innovation: An empirical examination of internet firms. J. Small Bus. Manag. 2009, 47, 263-286. [CrossRef]

96. Aniruddha, K.; Mital, A. Role of dynamic capabilities in innovation output of high-technology firms. Strat. Chang. 2016, 25, 401-425. [CrossRef]

97. Khattab, S.A. The impact of dynamic capability on innovation (an applied study on Jordanian pharmaceutical organizations). Eur. J. Bus. Manag. 2017, 9, 73-85.

98. Rothaermel, F.T.; Hess, A.M. Building dynamic capabilities: Innovation driven by individual-, firm-, and network-level effects. Organ. Sci. 2007, 18, 898-921. [CrossRef]

99. Ferreira, J.; Coelho, A.; Moutinho, L. Dynamic capabilities, creativity and innovation capability and their impact on competitive advantage and firm performance: The moderating role of entrepreneurial orientation. Technovation 2018, 92-93, 102061. [CrossRef] 
100. Hair, J.F., Jr.; Black, W.C.; Babin, B.J.; Anderson, R.E. Multivariate Data Analysis, 7th ed.; Pearson Education Limited: Harlow, UK, 2014; ISBN 978-1292021904.

101. Puspadewi, I.; Soetjipto, B.W.; Wahyuni, S.; Wijayanto, S.H. Managing paradox for the sustainability of social enterprises: An empirical study of forestry community cooperatives in Indonesia. J. Soc. Entrep. 2019, 10, 177-192. [CrossRef]

102. Wijanto, S.H. Metode Penelitian Menggunakan Structural Equation Modeling Dengan Lisrel 9; Lembaga Penerbit Fakultas Ekonomi UI: Jakarta, Indonesia, 2015; ISBN 9792454253.

103. Lee, J.-M.; Lee, S.-S. A study on the antecedent factors of performance and sustainability of social enterprises. J. Korea Ind. Inf. Syst. Soc. 2017, 22, 123-142. [CrossRef]

104. Lorenzo-Afable, D.; Lips-Wiersma, M.; Singh, S. "Social" value creation as care: The perspective of beneficiaries in social entrepreneurship. Soc. Enterp. J. 2020, 16, 339-360. [CrossRef]

105. Phillips, W.; Lee, H.; Ghobadian, A.; O’Regan, N.; James, P. Social innovation and social entrepreneurship: A systematic review. Group Organ. Manag. 2014, 40, 428-461. [CrossRef]

106. Sommerrock, K. Social Entrepreneurship Business Models; Palgrave Macmillan: Houndsmill, UK, 2010 ; ISBN 9781349326372.

107. Jiménez, D.; Sanz-Valle, R. Innovation, organizational learning, and performance. J. Bus. Res. 2011, 64, 408-417. [CrossRef]

108. Kump, B.; Engelmann, A.; Kessler, A.; Schweiger, C. Toward a dynamic capabilities scale: Measuring organizational sensing, seizing, and transforming capacities. Ind. Corp. Chang. 2019, 28, 1149-1172. [CrossRef]

109. Levine, A.B.; Koogut, B.; Kulatilaka, N. A New Approach to Funding Social Entreprises-Harvard Business Review. 2012. Available online: https:/ /hbr.org/2012/01/a-new-approach-to-funding-social-enterprises (accessed on 11 April 2020).

110. Campbell, K.E.; Marsden, P.V.; Hurlbert, J.S. Social resources and socioeconomic status. Soc. Netw. 1986, 8, 97-117. [CrossRef]

111. Nicotra, M.; Romano, M.; Del Giudice, M.; Schillaci, C.E. The causal relation between entrepreneurial ecosystem and productive entrepreneurship: A measurement framework. J. Technol. Transf. 2018, 43, 640-673. [CrossRef]

112. Arora, R.U. Measuring Financial Access; Griffith Business School: Southport, Australia, 2010; Volume 1.

113. Tchamyou, V.S. Education, lifelong learning, inequality and financial access: Evidence from African countries. Contemp. Soc. Sci. 2020, 15, 7-25. [CrossRef]

114. Ko, W.W.; Liu, G.; Yusoff, W.T.W.; Mat, C.R.C. Social entrepreneurial passion and social innovation performance. Nonprofit Volunt. Sect. Q. 2019, 48, 759-783. [CrossRef]

115. Dikaiakos, M.; Eteokleous, P.; Polyviou, A.; Kassinis, G.; Menelaou, M.; Nicolaou, N.; Polyviou, A. Global Entrepreneurship Monitor. 2017. Available online: https:/ / www.c4e.org.cy/reports/2017/C4E-Rep-2017-04.pdf (accessed on 11 April 2020).

116. PLUS. Platform Usaha Sosial. 2022. Available online: https://usahasosial.com/community/map/ (accessed on 24 June 2021).

117. Fornell, C.; Larcker, D.F. Evaluating structural equation models with unobservable variables and measurement error. J. Mark. Res. 1981, 18, 39-50. [CrossRef]

118. Burisch, R.; Wohlgemuth, V. Blind spots of dynamic capabilities: A systems theoretic perspective. J. Innov. Knowl. 2016, 1, 109-116. [CrossRef]

119. Collis, D.J.; Anand, B.N. The Limitations of Dynamic Capabilities-Harvard Business School Strategy Unit Working Paper. 2019. Available online: https://www.hbs.edu/ris/Publication\%20Files/20-029_517ce6b4-4c4a-492f-b56e-01f78886e03b.pdf (accessed on 21 September 2021).

120. Drnevich, P.L.; Kriauciunas, A.P. Clarifying the conditions and limits of the contributions of ordinary and dynamic capabilities to relative firm performance. Strat. Manag. J. 2011, 32, 254-279. [CrossRef] 